\title{
BEHOORT DIE SAAKLIKE OOREENKOMS AAN VORMVEREISTES ONDERWERP TE WORD?
}

\section{PJW Schutte*}

\section{$1 \quad$ Inleiding}

Die oordrag van eiendomsreg op onroerende goed in Nederland, Duitsland en Suid-Afrika bestaan uit twee elemente, naamlik: (1) registrasie in die akteskantoor (wat die objektiewe element is) ${ }^{1}$ en (2) die saaklike ooreenkoms, of wedersydse bedoeling om eiendomsreg oor te dra en te ontvang (wat die subjektiewe element is). ${ }^{2}$ Die saaklike ooreenkoms is 'n selfstandige ooreenkoms wat van die verbintenisskeppende ooreenkoms onderskei en geskei moet word en wat aan sy eie geldigheidsvereistes moet voldoen. In die geval van oordrag van roerende goed is geen vormvereistes op die saaklike ooreenkoms van toepassing nie (nie in Suid-Afrika nie, nie in Nederland nie en ook nie in Duitsland nie). Die ooreenkoms kan uitdruklik (mondeling) of stilswyend tot stand kom - gewoonlik word dit uit die omstandighede afgelei.

By die oordrag van onroerende goed is dit in Nederland en Duitsland egter nie voldoende dat die ooreenkoms uit die omstandighede afgelei word nie; dit moet aan vormvereistes voldoen en in 'n notariële akte vervat wees. Die grondslag

* BA, B-Juris, LL B; Medeprofessor in die Regte, Noordwes-Universiteit (Potchefstroomkampus).

1 Duitsland: §873 Bürgerliches Gesetzbuch (BGB); §20 Grundbuchordnung (GBO); Staudinger Sachenrecht I §873 Rdn 4; Westermann Sachenrecht I 254; Westermann Sachenrecht II 95. Nederland: Art 3:84 (1) Nieuw Burgerlijk Wetboek (NBW); AsserMijnssen Zakenrecht 162; Pitlo-Reehuis Goederenrecht 69; Snijders en Rank-Berenschot Goederenrecht 270.

2 Duitsland: §§873, 925 en 929 BGB; Wilhelm Sachenrecht 287; Baur Sachenrecht 36, 567568; Westermann Sachenrecht I 253 ev; Westermann Sachenrecht II 98; Staudinger Sachenrecht II §925 Rdn 2 en 9. In geval van onroerende goed staan die saaklike ooreenkoms as Auflassung bekend; by oordrag van roerende goed word daarna as die Einigung verwys. Alhoewel die NBW dit nie as ' $\mathrm{n}$ vereiste stel nie, word in die regsliteratuur algemeen aanvaar dat die saaklike ooreenkoms in Nederland wel ' $n$ vereiste vir die oordrag van eiendomsreg is en dat dit deel van die oordragshandeling vorm. Raadpleeg Asser-Mijnssen Goederenrecht 162, 164; Pitlo-Reehuis Goederenrecht 69; Snijders en Rank-Berenschot Goederenrecht 270; Mijnssen en Schut Levering en Overdracht 69. 
vir die vereistes is dat daar duidelikheid moet wees oor die feit dat die partye die bedoeling het om eiendomsreg oor te dra en dat daar wilsooreenstemming is betreffende die oordrag van eiendomsreg. Die besondere belang van grondeiendom en regsekerheid betreffende regshandelinge waardeur grond vervreem word, kan ook as redes aangemerk word.

In Suid-Afrika is daar geen vormvereistes betreffende die saaklike ooreenkoms in die geval van onroerende goed van toepassing nie. In hierdie artikel word die vraag ondersoek of daar in Suid-Afrika enige behoefte aan soortgelyke vormvereistes is. In die beantwoording van hierdie vraag sal regsbeginsels wat in die Nederlandse en die Duitse regstelsels op hierdie onderwerp van toepassing is, oorsigtelik bespreek word om vas te stel of daardie beginsels ook in die Suid-Afrikaanse reg oorgeneem kan word. ${ }^{3}$ Aangesien die registrasieproses die antwoord op hierdie vraag kan beïnvloed, sal enkele relevante aspekte van die proses ook ter sprake kom.

\section{Behoefte aan vormvereistes vir die saaklike ooreenkoms in Suid- Afrika}

\section{$2.1 \quad$ Bewys van saaklike ooreenkoms in Suid-Afrika}

In Duitsland en in Nederland moet bewys aan die Registrateur voorgelê word dat 'n saaklike ooreenkoms tot stand gekom het. Dit geskied deur voorlegging van 'n notariële akte wat aan die voorgeskrewe vormvereistes voldoen. ${ }^{4}$ In die geval van die oordrag van onroerende goed, is die tersaaklike omstandighede dus nie voldoende getuienis van die bestaan van die saaklike ooreenkoms nie. Anders as in Nederland en in Duitsland is geen vormvereistes in Suid-Afrika op

3 Die rede waarom na die Nederlandse en Duitse reg verwys word, is omdat hierdie regstelsels, soos die Suid-Afrikaanse reg, uit die Romeinse reg ontwikkel het en wesenlik dieselfde vereistes vir die oordrag van eiendomsreg in al drie stelsels aangetref word. Ooreenkomste en verskille in die onderskeie stelsels (naamlik Nederland, Duitsland en Suid-Afrika), vir sover dit vir die onderhawige bespreking van belang mag wees, sal uitgelig word, maar ' $n$ indringende vergelyking is nie werklik moontlik nie. Daar sal slegs gekonsentreer word op faktore wat 'n invloed uitoefen op die relevante aspekte van die saaklike ooreenkoms.

4 Sien die bespreking hier onder by punt 6 . 
die saaklike ooreenkoms van toepassing nie. Die ooreenkoms word nie op skrif gestel of notarieel verly nie, en dit word ook nie in die transportakte vervat nie. Die verkryger het geen aandeel aan die transportakte nie, en dit bevat ook geen verklaring deur hom dat hy eiendomsreg aanvaar nie. ${ }^{5}$ Daar kom dus nie veel tereg van die beginsel dat beide partye hulle medewerking moet gee by die oordrag van eiendomsreg nie.

Die Suid-Afrikaanse aktespraktyk is gegrond op die Plakkaat van 10 Mei 1529, wat sedert 1652 aan die Kaap op die oordrag van onroerende goed van toepassing was en wat voorgeskryf het dat oordrag van onroerende goed voor die gereg moet plaasvind (coram lege loci). Hierdie Plakkaat, aangevul deur Britse gewoontes, vorm die grondslag van die stelsel van oordrag van eiendomsreg op onroerende goed wat in Suid-Afrika toegepas word en het ook 'n invloed gehad op die Wet op Registrasie van Aktes. ${ }^{6}$ Aangesien die aktespraktyk op die Romeins-Hollandse reg gegrond is, is dit nie vreemd dat geen spoor van die saaklike ooreenkoms in die transportakte gevind kan word nie, want dié ooreenkoms was nog nie aan die Romeins-Hollandse reg bekend nie. Die aktespraktyk het egter nie tred gehou met ontwikkelinge wat in die materiële sakereg plaasgevind het nie, in besonder die konstruksie van oordrag deur die saaklike ooreenkoms wat aan Savigny ontleen is en wat in die SuidAfrikaanse reg oorgeneem is. Dit is opvallend dat die transportakte nie uitdrukking gee aan die beginsels van die materiële sakereg nie.

Omdat die saaklike ooreenkoms in Suid-Afrika nie op skrif gestel word nie, word dit uit die tersaaklike omstandighede wat met registrasie gaan, afgelei. Die vervreemder se bedoeling word byvoorbeeld afgelei uit die volmag waardeur hy opdrag gee aan die transportbesorger om oordrag te

5 Verlyding van die transportakte vind plaas deurdat die transportbesorger as verteenwoordiger van die vervreemder, voor die Registrateur verskyn en in sy teenwoordigheid die dokument onderteken terwyl die Registrateur dit attesteer.

$6 \quad$ Wet op Registrasie van Aktes 47 van 1937. Raadpleeg Badenhorst, Pienaar en Mostert Property 202-203; Nel Jones - Conveyancing 3-4; Heyl Grondregistrasie 4, 5 ev, 18, 68; Van der Merwe Sakereg 333; Laurens Saaklike Regte 74 ev; Lötz Onroerende Goed 11, $22 \mathrm{ev}$. 
bewerkstellig, ${ }^{7}$ die feit dat hy die bestaande titelakte wat in sy beheer is, beskikbaar stel, die feit dat hy die verkryger uit hoofde van die verbintenisskeppende ooreenkoms fisies in beheer van die saak stel, en die verklarings wat die transportbesorger as sy verteenwoordiger teenoor die Registrateur maak. ${ }^{8}$ Die verkryger se bedoeling kan afgelei word uit die feit dat hy 'n verbintenisskeppende ooreenkoms gesluit het wat die uiteindelike verkryging van eiendomsreg ten doel het, dat hy uit hoofde van daardie ooreenkoms fisies in beheer van die grondstuk gestel is, dat hy reëlings tref vir die verskaffing van waarborge om sy finansiële verpligtinge na te kom, dat hy die koopprys betaal, en uit die feit dat hy hereregte betaal en die daarmee gepaardgaande verklaring wat aan die Ontvanger van Inkomste gerig is, aflê. ${ }^{9}$ Daaruit kan afgelei word dat hy hom met die oordrag vereenselwig.

\subsection{Omringende omstandighede nie voldoende bewys nie}

Die omringende omstandighede waarna hierbo verwys is, is nie werklik betroubare maatstawwe om vas te stel wat die partye se werklike bedoeling was nie. Dit is dus nie noodwendig bewys daarvan dat ' $n$ geldige saaklike ooreenkoms inderdaad tot stand gekom het nie. Vervolgens sal aangetoon word dat dit heeltemal moontlik is dat geen saaklike ooreenkoms bestaan nie, selfs al het die vervreemder volmag verleen en al het die verkryger byvoorbeeld hereregte betaal.

Die feit dat die vervreemder volmag aan 'n transportbesorger verleen om registrasie te bewerkstellig, is nou wel 'n aanduiding daarvan dat hy die bedoeling het om eiendomsreg oor te dra, maar dit is nog nie deurslaggewend nie. Dit bevat geen verklaring deur die vervreemder dat hy inderdaad eiendomsreg oordra nie. Dit kan dus nie as die saaklike ooreenkoms of daardie deel van die ooreenkoms wat die vervreemder se verklaring bevat, beskou

7 Die volmag is die enigste dokument wat 'n verklaring deur die vervreemder persoonlik bevat en wat deur sy handtekening bevestig word. Dit is dus 'n belangrike bron van inligting vir die Registrateur. Raadpleeg Carey Miller en Pope Land Title 78; Jones Conveyancing 99.

8 Dit verskaf prima facie bewys van sy bedoeling om eiendomsreg oor te dra. Sien Laurens Saaklike Regte 262.

9 Sien Heyl Grondregistrasie 200. 
word nie. Die verklaring wat die transportbesorger namens die vervreemder teenoor die Registrateur aflê en waarin hy sê dat die vervreemder eiendomsreg oordra, kan ook nie as die saaklike ooreenkoms of 'n deel daarvan aanvaar word nie. Dit sou beteken dat die saaklike ooreenkoms tussen die vervreemder (transportbesorger) en die Registrateur gesluit word en dat dit eers tot stand kom wanneer registrasie plaasvind. Dit mag ook wees dat die vervreemder nie die bedoeling het om eiendomsreg oor te dra nie, selfs al het hy die volmag onderteken. Indien hy die volmag byvoorbeeld onderteken terwyl hy as gevolg van dwaling onder die indruk is dat hy eintlik 'n heel ander dokument teken (byvoorbeeld 'n opsie om te koop), ${ }^{10}$ kom geen saaklike ooreenkoms tot stand nie, omdat die vervreemder nie die bedoeling het om eiendomsreg oor te dra nie. ${ }^{11}$ Die vervreemder mag ook nog te eniger tyd voor registrasie en om watter rede ook al, van mening verander en die volmag herroep, in welke geval registrasie nie oordrag van eiendomsreg sal bewerkstellig nie, want hy het op daardie tydstip nie meer die bedoeling om eiendomsreg oor te dra nie. ${ }^{12}$ As gevolg van 'n oorsig of 'n fout kan dit ook gebeur dat die transportakte geregistreer word sonder dat die verbandakte gelyktydig geregistreer word, of sonder dat die waarborg vir betaling van die koopprys gelewer is. Ook hier kan geargumenteer word dat die vervreemder nie die bedoeling het dat eiendomsreg deur registrasie oorgaan nie, selfs al het hy die volmag onderteken. $^{13}$

Dit is veral die feit dat daar geen aanduiding is daarvan dat die verkryger inderdaad oordrag van eiendomsreg aanvaar nie, wat problematies is. Die hereregteverklaring en - kwitansie is niks anders nie as fiskale dokumente. Die doel daarmee is om te verseker dat die volle hereregte betaal word en om te voorkom dat die betaling van hereregte ontwyk word deur kansellasie van ' $n$

10 Of as hy onder die indruk verkeer dat hy onontwikkelde grond oordra, terwyl hy in werklikheid grond met geboue daarop oordra ('n geval van error in corpore).

11 Carey Miller Acquisition 167-168; Preller v Jordaan 19561 SA 483 (A).

12 Anders as in Nederland en in Duitsland waar die partye aan die saaklike ooreenkoms gebonde is, kan die vervreemder nog te eniger tyd voor registrasie sy bedoeling verander of die volmag herroep, omdat dit 'n eensydige dokument is. Indien hy regtens geen rede het om sy bedoeling te herroep nie, sal hy natuurlik op grond van die verbintenisskeppende ooreenkoms verplig kan word om eiendomsreg oor te dra.

13 Sien ook Heyl Grondregistrasie 212. 
vorige koop en die substitusie van 'n nuwe kontrak. ${ }^{14}$ Dit verskaf nog nie bewys daarvan dat die verkryger inderdaad die bedoeling het om eiendomsreg deur registrasie te aanvaar nie. Selfs al het hy in die stadium waarop hereregte betaal is, die bedoeling om eiendomsreg (op 'n onbekende dag in die toekoms) te ontvang, kan sy bedoeling daarna, om watter rede ook al, verander, sodat hy op die tydstip van registrasie nie meer die bedoeling het om eiendomsreg te ontvang nie. Dit mag byvoorbeeld wees dat hy intussen, nadat hereregte betaal is, fisies in beheer van die saak geplaas word, maar dat hy weier om oordrag te aanvaar omdat die grondstuk nie voldoen aan die kenmerke waarop ooreengekom is nie. Selfs al sou hy fisiese beheer aanvaar, sou dit ook nie noodwendig deurslaggewend wees nie. In elk geval sou dit in baie gevalle beteken dat die saaklike ooreenkoms eers tot stand kom nadat registrasie plaasgevind het. Daar is dus nie werklik enige getuienis dat die verkryger eiendomsreg inderdaad aanvaar nie. ${ }^{15}$

Dit is opvallend dat die verkryger bykans geen aandeel aan die registrasieproses het nie. Nêrens in die Wet op Registrasie van Aktes ${ }^{16}$ word iets gesê omtrent aanvaarding van die oordrag deur die verkryger nie. Hy vervul ook geen rol by die registrasiehandeling nie. Die transportbesorger verskyn as verteenwoordiger van die vervreemder voor die Registrateur en verly in sy teenwoordigheid die transportakte, terwyl die Registrateur dit attesteer en sy ampseël daarop aanbring. ${ }^{17} \mathrm{Heyl}$ doen selfs aan die hand dat die vereiste dat die verkryger die oordrag moet aanvaar, in geval van oordrag van eiendomsreg op onroerende goed laat vaar kan word, omdat sy medewerking nie nodig is nie. ${ }^{18}$ Met hierdie standpunt kan egter nie saamgestem word nie, aangesien dit op 'n verwerping van die saaklike ooreenkoms neerkom. ${ }^{19}$

14 Carey Miller en Pope Land Title 112.

15 Ook Lötz Onroerende Goed 6 meen dat daar niks is wat die verkryger se bedoeling kan staaf nie. Daar kan slegs afleidings gemaak word uit die feit dat hy hom met oordrag vereenselwig.

16 Wet op Registrasie van Aktes 47 van 1937.

17 Sien art 20 en 50 van die Wet op Registrasie van Aktes 47 van 1937; Carey Miller Acquisition 181; Carey Miller en Pope Land Title 84; Badenhorst, Pienaar en Mostert Property 210, 214-215; Desai v Desai 19961 SA 141 (A) 148-149.

18 Heyl Grondregistrasie 215.

19 Voet ad Digesta 41.1.38 huldig die mening dat aanvaarding deur die verkryger in geval van oordrag van onroerende goed voor die gereg nie nodig is nie. Sien ook Heyl 
Die vervreemder self vervul slegs 'n indirekte en ondergeskikte rol, want die transportbesorger tree as sy verteenwoordiger op wanneer hy die transportakte opstel, dit voor die Registrateur verly en teenoor hom verklaar dat die vervreemder eiendomsreg aan die verkryger oordra. ${ }^{20} \mathrm{Gesien}$ in die lig van die beginsel dat beide partye hulle samewerking moet gee om oordrag te bewerkstellig, is dit ironies dat die partye se betrokkenheid tot die minimum beperk is: hulle maak geen wedersydse verklarings nie, hulle neem nie deel aan die opstel en verlyding van die akte nie en het ook nie direk deel aan die registrasiehandeling nie. ${ }^{21}$ Die partye wat direk betrokke is, is die transportbesorger in sy hoedanigheid as verteenwoordiger van die vervreemder, en die Registrateur van aktes. ${ }^{22}$

Die gevolgtrekking uit bostaande bespreking is dat die omstandigheidsgetuienis (soos die volmag en hereregtekwitansie) die saak niks verder voer as wat die verbintenisskeppende ooreenkoms reeds doen nie. Alhoewel dit die afleiding regverdig dat die partye die bedoeling het om eiendomsreg oor te dra, is dit nog nie bewys dat ' $n$ afsonderlike saaklike ooreenkoms, waar ooreengekom is dat eiendomsreg deur registrasie oorgedra word, tot stand gekom het nie. ${ }^{23}$ Daar is nog geen getuienis dat wilsooreenstemming deur bewuste samewerking tussen

Grondregistrasie 157. Anders as wat die geval in die Romeins-Hollandse reg was, is ' $n$ geldige saaklike ooreenkoms in Suid-Afrika ' $n$ vereiste. Aanvaarding deur die verkryger is dus wel nodig, sodat dit duidelik sal wees dat daar wilsooreenstemming is.

20 Laurens Saaklike Regte 262; Heyl Grondregistrasie 157-158. Die vervreemder se persoonlike betrokkenheid eindig wanneer hy die volmag onderteken waardeur die transportbesorger opdrag gegee word. Hy onderteken die transportakte nie persoonlik nie en hy maak ook nie persoonlik enige verklarings in die akte nie. Die transportakte bevat slegs ' $n$ verklaring deur die Registrateur van aktes in die vorm van 'n monoloog.

21 Die transportbesorger as verteenwoordiger van die vervreemder en die Registrateur van aktes, is die aktiewe partye tydens die registrasiehandeling. Lötz Onroerende Goed 12-13 beskryf registrasie as 'n vorm van konstruktiewe lewering, omdat die enigste betrokkenheid van die partye bestaan uit die bedoeling om eiendomsreg oor te dra. Verder Weeks v Amalgamated Agencies 1920 AD 218; Erikson Motors v Protea Motors 19733 SA 685 (A) 694; Van Rensburg en Van der Merwe 1978 THRHR 113; Schoeman en Schoeman Property 110; Heyl Grondregistrasie 197-198.

22 Hy verwys onder andere na die feit dat die transportbesorger voor hom verskyn en verklaar dat hy namens die vervreemder eiendomsreg aan die verkryger oordra. Vergelyk die oordragsklousule en die ontheffingsklousule.

23 Die omstandigheidsgetuienis sou waarskynlik voldoende gewees het indien die vraag, soos in die Romeins-Hollandse reg, bloot was of die partye wedersyds die bedoeling het om eiendomsreg oor te dra en te ontvang. 
die partye bereik is nie. ${ }^{24}$ Dit is dus heeltemal moontlik dat 'n saaklike ooreenkoms ontbreek, selfs al is volmag verleen en al is hereregte betaal. ${ }^{25}$ Daar is derhalwe ook nie duidelikheid betreffende die presiese tydstip waarop die saaklike ooreenkoms tot stand kom nie, byvoorbeeld op die tydstip waarop die volmag onderteken word, of die tydstip waarop die hereregte betaal word, of die tydstip waarop die verkryger fisiese beheer oor die saak neem.

Dit is natuurlik van die allergrootste belang dat daar wel sekerheid moet bestaan betreffende die tydstip waarop die saaklike ooreenkoms tot stand kom. Van daardie oomblik af is die ooreenkoms bindend, en dit bly voortbestaan tot op die tydstip dat registrasie plaasvind. ${ }^{26}$ Dit is ook makliker om vas te stel of die geldigheidsvereistes nagekom is, aangesien hierdie vraag slegs met verwysing na 'n bepaalde tydstip beoordeel kan word. Indien die vervreemder byvoorbeeld sy handelingsbevoegdheid verloor (indien hy kranksinnig verklaar word, of onder kuratele geplaas word), kan hy nie meer 'n geldige saaklike ooreenkoms sluit nie. 'n Mens sal dus wil weet op watter tydstip die ooreenkoms tot stand kom, sodat jy kan beoordeel of die verlies aan handelingsbevoegdheid enige invloed het. $^{27}$

\subsection{Gevolge van onvoldoende getuienis}

Die feit dat daar nie oortuigende skriftelike getuienis betreffende die totstandkoming van 'n geldige saaklike ooreenkoms is nie en dat dit uit twyfelagtige omstandigheidsgetuienis afgelei moet word, het tot gevolg dat die Registrateur, wat 'n aktiewe rol in die registrasieproses vervul, nie sy opdrag na behore kan uitvoer nie. Hy het naamlik 'n sorgsaamheidsplig om toe te sien dat die registers akkuraat saamgestel en in stand gehou word, sodat dit strek tot

24 Om uit die volmag en betaling van hereregte die afleiding te maak dat die partye ' $n$ ooreenkoms bereik het, doen die reëls met betrekking tot die totstandkoming van regshandelinge geweld aan.

25 Maar sien Carey Miller Acquisition 164, 168 wat die mening uitspreek dat die omringende omstandighede byna altyd die afleiding sal regverdig dat daar 'n saaklike ooreenkoms was. Dit is volgens hom afdoende bewys.

26 Dit is twyfelagtig of die partye in Suid-Afrika aan die ooreenkoms gebonde is. In Nederland en Duitsland is die partye wel daaraan gebonde, en daar word aan die hand gedoen dat dit ook in Suid-Afrika die geval behoort te wees.

27 Dieselfde geld ten opsigte van al die ander geldigheidsvereistes. 
regsekerheid. Dit is derhalwe sy taak om seker te maak dat registrasie toelaatbaar en onaanvegbaar is. Hy moet nie net toesien dat die voorgeskrewe formaliteite en prosedure vir registrasie nagekom is nie, maar ook dat die vereistes van die materiële reg vir die oordrag van eiendomsreg nagekom is. Indien dit nie nagekom is nie, moet die aansoek om registrasie verwerp word en gebreke moet eers reggestel word voordat dit weer ingedien word. ${ }^{28}$

In Suid-Afrika moet die Registrateur hom verlaat op die inhoud van die transportakte en die ondersteunende dokumente, ten einde vas te stel of gemelde vereistes wel nagekom is. ${ }^{29}$ Die probleem is egter dat die saaklike ooreenkoms in nie een van hierdie dokumente tot uitdrukking kom nie. Soos reeds aangetoon, bevat die transportakte nie die saaklike ooreenkoms nie, en die volmag en hereregtekwitansie is ook nie afdoende bewys van die ooreenkoms nie. Die Registrateur doen ook nie enige ondersoek buite hierdie dokumente om nie. ${ }^{30}$ Die feit dat die saaklike ooreenkoms nie op skrif gestel word nie (en nie in die transportakte vervat is nie), ontneem die Registrateur dus waardevolle inligting. Hy is nie werklik in 'n posisie om met sekerheid te bepaal of 'n geldige saaklike ooreenkoms inderdaad tot stand gekom het nie. Dit is daarom heeltemal moontlik dat registrasie kan plaasvind sonder dat daar 'n geldige saaklike ooreenkoms was. Indien dit wel sou gebeur, gaan eiendomsreg natuurlik nie oor nie, omdat die vereistes vir oordrag van eiendomsreg ontbreek. Registrasie het dan tot gevolg dat die registers foutief is, aangesien iemand in die registers as eienaar aangeteken word terwyl hy dit nie is nie. ${ }^{31}$

Hierdie gebrek aan bewys van die saaklike ooreenkoms in geval van die oordrag van eiendomsreg op onroerende goed, is onverstaanbaar as dit vergelyk word met die praktyk wat in die akteskantoor gevolg word wanneer

28 Reg 45 (1); Carey Miller en Pope Land Title 123-125; Badenhorst, Pienaar en Mostert Property 210; 215, 218.

29 Die betrokke dokumente is ' $n$ veiligheidsklep om te verseker dat ' $n$ regmatige registrasiehandeling plaasvind. Lötz Onroerende Goed 64.

30 Badenhorst, Pienaar en Mostert Property 221-222; Heyl Grondregistrasie 198-199. Verg in hierdie verband ook Gardens Estate v Lewis 1920 AD 144, 148-150 waar die hof beslis het dat die bedoeling van die partye bepaal moet word na aanleiding van wat in die tersaaklike transportakte openbaar word.

31 Sien Baur Sachenrecht 166; Kuntze et al Grundbuchrecht 68. 
beperkte saaklike regte geregistreer word. In hierdie geval word aangedring op skriftelike magtiging deur die partye wat dien as bewys daarvan dat 'n geldige saaklike ooreenkoms tot stand gekom het. ${ }^{32}$ Daar word aan die hand gedoen dat dit ook in geval van die oordrag van eiendomsreg gedoen behoort te word.

Dit is natuurlik een van die kenmerke van 'n negatiewe stelsel dat daar nie met sekerheid gesê kan word dat die persoon wat as eienaar geregistreer is, werklik eienaar is en of hy oor die bevoegdheid beskik om die saak te vervreem nie. Dit is waarskynlik ook die rede waarom die staat in 'n negatiewe stelsel nie bereid is om enige waarborge betreffende die korrektheid van die registers te gee nie. ${ }^{33}$ Dit spreek vanself dat indien hierdie negatiewe eienskappe, wat by afgeleide wyses van eiendomsverkryging onsekerheid skep, uit die weg geruim kan word, dit gedoen behoort te word. ${ }^{34}$ Die feit dat die Registrateur nie werklik enige kennis betreffende die saaklike ooreenkoms het nie (wat deur die huidige aktespraktyk teweeg gebring word), werk juis die onsekerhede wat die negatiewe stelsel meebring, in die hand. Die oogmerke wat met registrasie nagestreef word, naamlik regsekerheid en sekuriteit van titel, die akkuraatheid en volledigheid van die registers, word dus deur die bestaande praktyk ondermyn. Registrasie is juis bedoel om twyfel rakende die regte van die persoon wat as eienaar geregistreer is, uit die weg te ruim. ${ }^{35}$

Een rede waarom die staat die korrektheid van die registers kan waarborg in 'n positiewe stelsel soos in Duitsland toegepas, is waarskynlik omdat daar duidelikheid bestaan oor die vraag of 'n geldige saaklike ooreenkoms tot stand gekom het al dan nie. Die feit dat 'n abstrakte stelsel in Suid-Afrika toegepas word, verminder darem die onsekerhede wat met 'n negatiewe stelsel gepaard

32 Carey Miller en Pope Land Title 100-101: "... the registrar requires the written authority of the parties involved and this ensures that the intention requirement is satisfied". Verder Carey Miller Acquisition 203; Jones Conveyancing 207-211, 248-252.

33 Sien Pienaar 1986 CILSA 238. Volgens Carey Miller Acquisition 169 is dit juis die vereiste dat die bedoeling van die partye in ag geneem moet word, wat tot gevolg het dat daar onsekerheid heers en dat die staat nie bereid is om waarborge te gee nie. Die vereiste van 'n saaklike ooreenkoms is dus in stryd met 'n positiewe stelsel waar wel waarborge gegee word.

34 Die wysigings wat in Nederland deur die NBW teweeggebring is, was juis daarop gerig om die onsekerhede van die negatiewe stelsel uit te skakel en groter sekerheid te skep. 
gaan: as nietigheid van die grondliggende ooreenkoms irrelevant is, is die kans dat oordrag aanvegbaar sal wees soveel kleiner.

\section{$2.4 \quad$ Samevatting}

Bogenoemde bespreking het aan die lig gebring dat daar geen skriftelike bewys van die saaklike ooreenkoms in die Suid-Afrikaanse reg is nie. Die saaklike ooreenkoms word afgelei uit die omringende omstandighede wat met registrasie gepaard gaan. Daar is egter aangetoon dat sulke omstandighede nie afdoende bewys daarvan verskaf dat 'n geldige saaklike ooreenkoms wel bestaan nie. Die feit dat daar onvoldoende getuienis is betreffende die bestaan van die saaklike ooreenkoms, verhinder die Registrateur om sy werk behoorlik uit te voer, en dit bring weer mee dat registrasie kan plaasvind sonder dat daar aan die materieelregtelike vereistes vir die oordrag van eiendomsreg voldoen is. Die moontlikheid bestaan dus dat die registers foutief kan wees en nie ' $n$ getroue weergawe van die werklike regsposisie is nie. Daar bestaan derhalwe ' $n$ behoefte in die Suid-Afrikaanse reg aan groter duidelikheid betreffende die vraag of, en indien wel op watter tydstip, 'n geldige saaklike ooreenkoms tot stand gekom het. Hierdie behoefte word veral deur die toepassing van die negatiewe stelsel op die voorgrond geplaas. ${ }^{36}$ Alhoewel die Suid-Afrikaanse stelsel relatief betroubaar is, ${ }^{37}$ is daar wel ruimte vir verbetering.

\section{Vormvereistes in Nederland en in Duitsland van toepassing}

Hierbo is aangetoon dat registrasie in Suid-Afrika kan plaasvind, selfs al is daar nie aan die vereistes van die materiële reg voldoen nie, in besonder as daar nie 'n geldige saaklike ooreenkoms is nie. Alhoewel eiendomsreg nie oorgedra word nie, sal 'n foutiewe registrasie meebring dat die registers foutief is, wat derde partye weer kan benadeel. By die oordrag van onroerende goed bestaan daar dus ' $n$ behoefte aan voldoende bewys dat 'n saaklike ooreenkoms

36 In 'n negatiewe stelsel verskaf die staat geen waarborg betreffende die korrektheid van die registers nie. Indien daar registrasiefoute gemaak word, geskied dit ten koste van bona fide verkrygers.

37 Pienaar 1986 CILSA 238. 
inderdaad tot stand gekom het. Vervolgens sal die regsposisie in die Nederlandse en die Duitse reg ondersoek word, ten einde vas te stel hoe hierdie vraagstuk daar aangepak word. Die oogmerk is om aanbevelings te maak oor hoe die leemte in die Suid-Afrikaanse reg gevul kan word. ${ }^{38}$ Wat opval, is dat die saaklike ooreenkoms in genoemde twee stelsels nie uit die omstandighede afgelei word nie. As gevolg van die besondere belang van grondeiendom en die behoefte aan sekerheid betreffende regshandelinge waardeur grond vervreem word, moet skriftelike bewys in hierdie verband aan die Registrateur voorgelê word. Die saaklike ooreenkoms word dus aan vormvereistes onderwerp.

\subsection{Nederland}

In Nederland word onroerende goed deur "inschrijving van een daartoe bestemde, tussen partijen opgemaakte notariële akte" in die openbare registers gelewer. Daar word aanvaar dat die notariële akte die saaklike ooreenkoms bevat. ${ }^{39}$ Die notariële akte is tegelyk ook transportakte (of akte van levering) en moet voldoen aan die vormvoorskrifte wat vir notariële aktes voorgeskryf word. ${ }^{40}$ Aangesien die saaklike ooreenkoms uit die wedersydse bedoeling bestaan om eiendomsreg oor te dra en te ontvang, moet die notariële akte (transportakte) 'n verklaring deur die vervreemder bevat dat hy eiendomsreg oordra en ook 'n verklaring deur die verkryger dat hy eiendomsreg aanvaar. ${ }^{41}$ Die verklarings word opgestel voor die notaris wat die akte opstel, en die akte moet deur beide partye onderteken word. ${ }^{42}$ Die transportakte is dus tweesydig, aangesien beide partye hulle medewerking gee by die opstel daarvan en dit uit

38 Sien die bespreking by punt 7 hier onder.

39 Art 3:89 NBW; Asser-Mijnssen Goederenrecht 169, 223-224; Pitlo-Reehuis Goederenrecht 118; Mijnssen en Schut Levering en Overdracht 73; Algra Burgerlijk Recht 187. AsserBeekhuis Zakenrecht 237, 239.

40 Raadpleeg art 1, 25, 26 en 30 van die Wet op het Notarisambt en art 18 van die Kadasterwet.

41 Asser-Mijnssen Goederenrecht 223; Asser-Mijnssen Zakenrecht 257. Indien die akte slegs die verklaring van die vervreemder bevat, sou hy die akte kon laat registreer en eiendomsreg op die verkryger oordra, sonder dat hy daarvan bewus is of daartoe meegewerk het.

42 Art 3:89 (1) NBW vereis 'n tussen partijen opgemaakte notariële akte. Dit is nietemin moontlik dat die onderskeie verklarings in afsonderlike dokumente vervat kan word. 
die akte duidelik is dat daar wilsooreenstemming is betreffende die oordrag van eiendomsreg.

Die ooreenkoms kom tot stand met ondertekening van die akte. Van daardie tydstip af is die ooreenkoms bindend, met die gevolg dat die partye hulle nie meer daaraan kan onttrek nie en enigeen van die partye die nodige stappe kan doen om registrasie te bewerkstellig. Indien die verkoper sou weier om die akte te teken nadat die koper sy verpligtinge nagekom het, maak hy hom skuldig aan wanprestasie. ${ }^{43}$ Indien die koper sou weier om sy samewerking te gee ten opsigte van die opstel van die akte, is hy in versuim. ${ }^{44}$ In die geval van oordrag van onroerende goedere, is dit dus geregverdig om, wat die Nederlandse reg betref, die transportakte wat die wilsverklarings van die partye bevat, as die regtens voorgeskrewe vorm te beskou waarin die saaklike ooreenkoms tot uitdrukking kom. ${ }^{45}$

\subsection{Duitsland}

In Duitsland word onderskei tussen materieelregtelike geldigheidsvereistes vir die saaklike ooreenkoms en die vereistes wat deur die formele reg vir registrasie voorgeskryf word. Ingevolge $\$ 925$ BGB moet die volgende materieelregtelike vereistes nagekom word alvorens 'n geldige saaklike ooreenkoms tot stand kan kom: beide partye moet in mekaar se teenwoordigheid teenoor ' $n$ notaris of ander bevoegde persoon verklaar dat hulle die bedoeling het om eiendomsreg oor te dra en te ontvang. Van hierdie tydstip af is die ooreenkoms bindend. Dit is moontlik dat die partye verteenwoordig kan word. Dit gebeur byvoorbeeld dikwels dat 'n notaris (maar nie die notaris voor wie die verklaring afgelê word nie) een, of selfs beide,

43 Die koper kan die kontrak kanselleer, of hy kan reële eksekusie afdwing en die verkoper regstreeks tot nakoming verplig. Art 3:300, 6:74 en 6:265 NBW; Asser-Mijnssen Goederenrecht 233-234; Asser-Beekhuis Zakenrecht 240. Sien ook Wilhelm Sachenrecht 2912-293 ivm die vraag of die vervreemder op grond van die verbintenisskeppende ooreenkoms verplig kan word om die saaklike ooreenkoms (Auflassung) te sluit.

$44 \mathrm{Hy}$ is verplig om sy samewerking te gee. Asser-Mijnssen Zakenrecht 263.

45 Asser-Mijnssen Goederenrecht 162, 164. Dit wil voorkom asof hy die standpunt van Wiarda en Van Oven in hierdie opsig oorgeneem het. Hierdie siening kan nie op die SuidAfrikaanse reg van toepassing gemaak word nie, omdat die saaklike ooreenkoms nie in die transportakte opgeneem word nie. 
partye verteenwoordig en dit is ook moontlik dat die koper as verteenwoordiger van die verkoper optree. ${ }^{46}$

Aangesien die aktespraktyk uit die Germaanse stelsel van oordrag voor die gereg ontwikkel het, ${ }^{47}$ moes die partye aanvanklik voor die registrasiebeampte (gereg) verskyn en die saaklike ooreenkoms in sy teenwoordigheid aflê. Vandag verskyn die partye of hulle verteenwoordigers egter nie meer voor die Registrateur nie en hulle maak ook geen verklarings in sy teenwoordigheid nie. Die verklarings waaruit die saaklike ooreenkoms manifesteer, word voor die notaris afgelê. Hy moet toesien dat alle stappe wat vir registrasie vereis word, gedoen is en hy moet die relevante dokumentasie by die registrasiekantoor indien. Dit is belangrik om daarop te let dat $\$ 925$ BGB (materiële reg) nie voorskryf dat die ooreenkoms op skrif gestel of notarieel verly moet word om geldig te wees nie. Dit is dus voldoende indien die verklarings mondeling afgelê word. $^{48}$

Notariële verlyding van die saaklike ooreenkoms word nietemin deur die formele reg (aktesregistrasie) as vereiste vir registrasie voorgeskryf. Ingevolge §29 Grundbuchordnung (GBO) kan oordrag slegs geregistreer word indien daar in die voorgeskrewe vorm bewys gelewer word dat die saaklike ooreenkoms bestaan, omdat die Registrateur daarvan oortuig moet word dat die vereistes van die materiële reg nagekom is. ${ }^{49}$ Die vorm wat voorgeskryf word, is naamlik

46 Verg §§167, 177 en 925 BGB; Baur Sachenrecht 248; Wilhelm Sachenrecht 287, 290-291; Kuntze et al Grundbuchrecht 532-533; Staudinger Sachenrecht II §925 Rdn 83; Westermann Sachenrecht II 106; Wieling Sachenrecht 1992333.

47 Sien Baur Sachenrecht 247-248; Wilhelm Sachenrecht 289; Staudinger Sachenrecht II §925 Rdn 77-79, 111.

48 Daar kan nie gesê word dat die notariële akte die regtens voorgeskrewe vorm is waarin die saaklike ooreenkoms tot uiting kom nie. Kuntze et al Grundbuchrecht 531; Staudinger Sachenrecht II §925 Rdn 76, 86; Fuchs-Wissermann 1977 Rechtspfleger 10, FuchsWissermann 1978 Rechtspfleger 431-432; Pienaar 1986 CILSA 243.

$49 \S 29$ Grundbuchordnung (GBO) moet saamgelees word met $\S 20$ GBO wat bepaal dat registrasie slegs kan plaasvind indien daar ' $n$ saaklike ooreenkoms is (die partye moet hulle bedoeling om eiendomsreg oor te dra verklaar). Dit neem die saak eintlik nie veel verder as wat $\S \S 873$ en 925 reeds doen nie. Raadpleeg Baur Sachenrecht 165, 168, 247; Wilhelm Sachenrecht 215, 289; Kuntze et al Grundbuchrecht 93-94, 108, 110, 498, 517; Wieling Sachenrecht 1992 252, 255, 333; Westermann Sachenrecht I 106-107; Westermann Sachenrecht II 69, 96, 107; Fuchs-Wissermann 1977 Rechtspfleger 9 ev, 1978 Rechtspfleger 431 ev; Ertl 1980 Rechtspfleger 49; Huhn 1977 Rechtspfleger 199. Maar sien Staudinger Sachenrecht I §873 Rdn 148-149. 
dat 'n öffentliche Urkunde of 'n öffentlich beglaubigte Urkunde van die saaklike ooreenkoms opgestel en aan die Registrateur voorgelê moet word. As dit nie gedoen word nie, moet die aansoek om registrasie afgewys word. ${ }^{50}$ 'n Öffentlichen Urkunde word opgestel deur 'n notaris of ander openbare amptenaar (öffentliche Behörde) wat met die bevoegdheid beklee is om openbare dokumente op te stel. ${ }^{51}$ Die akte moet voldoen aan die voorgeskrewe vormvereistes wat vir notariële aktes voorgeskryf word, soos byvoorbeeld dat die notaris sy seël of stempel daarop moet aanbring en dit moet onderteken. ${ }^{52}$ In die akte moet die notaris bevestig dat die partye voor hom verskyn het en die betrokke verklarings afgelê het. ${ }^{53}$ Die öffentlichen Urkunde dien dus as bewys daarvan dat die saaklike ooreenkoms tot stand gekom het, 'n feit wat deur die Registrateur by voorlegging van die dokument aanvaar word. ${ }^{54}$ In 'n öffentlich beglaubigte Urkunden word die egtheid van die partye se handtekeninge, of die feit dat die dokument deur die betrokke persone onderteken is, bevestig en nie die egtheid van die verklarings nie. Dit dien as bewys daarvan dat die verklarings wat in die dokument vervat is, werklik deur die persone wat daarin genoem word, gemaak is. ${ }^{55}$

Die bespreking hierbo het aangetoon dat dit in Nederland en in Duitsland nie voldoende is om uit die omstandighede afleidings te maak nie; skriftelike bewys moet aan die Registrateur voorgelê word, sodat hy/sy oortuig sal wees van die bestaan en inhoud van die saaklike ooreenkoms. Die volgende redes word aangevoer ter regverdiging van die vereiste dat bewys van die saaklike

50 Notariële verlyding is dus nie ' $n$ geldigheidsvereiste vir die saaklike ooreenkoms nie, maar dit word wel vereis vir registrasiedoeleindes. Sien Baur Sachenrecht 248.

51 Beurkundung deur ' $n$ notaris is ' $n$ amptelike handeling van staatsweë, soortgelyk aan die optrede deur 'n huweliksbevestiger.

52 Sien $\$ 29$ Grundbuchordnung. Voorts moet die vormvereistes betreffende die opstel van öffentliche Urkunden soos vervat in $\S 6$ ev van die Beurkundungsgesetz (BeurkG) van 1969 en $\$ 168$ Gesetz über die Angelegenheiten der freiwilligen Gerichtsbarkeit (FGG) van 1898 nagekom word. Kuntze et al Grundbuchrecht 656-657, 660; Wieling Sachenrecht 1992 333; Fuchs-Wissermann 1978 Rechtspfleger 432; Haegele 1967 Rechtspfleger 3536.

53 Hy bevestig die egtheid van die verklarings.

54 In die geval van eksekusie word die verklaring van een party deur die hofbevel vervang. §925 BGB; §894 Zivilprozeßordnung (ZPO); Baur Sachenrecht 248; Wilhelm Sachenrecht 312; Westermann Sachenrecht I 256; Westermann Sachenrecht II 106; Wieling Sachenrecht 1990 279; Wieling Sachenrecht 1992333.

$55 \S 129$ BGB; §167 Zivilprozeßordnung en §20 Bundesnotarordnung van 1961 (BnotO); Kuntze et al Grundbuchrecht 665-668; Haegele 1967 Rechtspfleger 35. 
ooreenkoms in die voorgeskrewe vorm aan die Registrateur voorgelê moet word: ${ }^{56}$

a) Die registrateur vervul ' $n$ aktiewe rol in die registrasieproses en moet toesien dat die dokumentasie wat ingedien word, korrek is en dat registrasie onaanvegbaar is. Hy/sy moet derhalwe daarvan oortuig word dat die saaklike ooreenkoms, wat deur die materiële reg voorgeskryf word, wel bestaan.

b) Dit maak duidelik dat die partye inderdaad bedoel om eiendomsreg oor te dra en te ontvang en daar word verseker dat hulle die gevolge van hulle handelinge deeglik oorweeg het. ${ }^{57}$

c) Die vormvereistes dra daartoe by om bedrieglike vervreemdings in die tydperk tussen totstandkoming van die saaklike ooreenkoms en registrasie te voorkom. ${ }^{58}$

d) Dit is in belang van die regsverkeer dat die grondregister met die ware toedrag van sake ooreenstem, omdat eiendomsreg in onroerende goed 'n belangrike privaatregtelike en publiekregtelike funksie in die samelewing vervul. Indien daar sekerheid is oor die feit dat 'n saaklike ooreenkoms tot stand gekom het, asook die tydstip waarop dit gebeur het, word die moontlikheid van foutiewe inskrywings in die register uitgeskakel. Die vormvereistes is in die openbare belang, omdat dit die registrateur help om toe te sien daartoe dat die grondregister ooreenstem met die werklikheid, wat weer openbare vertroue in die register bevorder. ${ }^{59}$

Bewys van die saaklike ooreenkoms bring egter nog geen sekerheid dat die vervreemder op die tydstip van registrasie inderdaad ingestem het tot registrasie nie (dat sy toestemming nog bestaan nie). Afgesien daarvan dat die vervreemder en die verkryger voor die notaris moet verklaar dat hulle bedoel

56 Raadpleeg Staudinger Sachenrecht I §873 Rdn 156; Staudinger Sachenrecht II §925 Rdn 75; Kuntze et al Grundbuchrecht 531, 646; Wilhelm Sachenrecht 289; Wieling Sachenrecht 1992333.

57 Die notaris wat ' $n$ regskundige persoon is, moet die partye behoorlik inlig oor die gevolge van hulle optrede en die verloop van die proses.

58 Sien Wilhelm Sachenrecht 289.

59 Haegele 1967 Rechtspfleger 34; Kuntze et al Grundbuchrecht 656, 660, 664; FuchsWissermann 1978 Rechtspfleger 432. 
om eiendomsreg oor te dra (saaklike ooreenkoms), moet die vervreemder in Duitsland ook nog toestemming verleen tot registrasie (die Eintragungsbewilligung ingevolge $\$ 19$ GBO), sodat die Registrateur absoluut seker sal wees dat registrasie mag plaasvind. ${ }^{60}$ Die doel is om te verseker dat die register in ooreenstemming is met die feitlike regsposisie. Dit sal dan net in uitsonderlike gevalle gebeur dat die register foutief is. ${ }^{61}$

Wilhelm ${ }^{62}$ argumenteer egter dat toestemming behoudens enkele uitsonderings onnodig is. In die lig van die feit dat Auflassung (saaklike ooreenkoms) 'n vereiste is, is verdere toestemming deur die vervreemder nie nodig nie. Die Duitse juriste is nie eenstemmig oor hierdie aangeleentheid nie, maar ongelukkig kan hier nie indringender op hierdie kwessie ingegaan word nie. Daar word volstaan met die opmerking dat toestemming tot registrasie, afgesien van bewys van die saaklike ooreenkoms, 'n afsonderlike vereiste vir registrasie is. Alhoewel die verbintenisskeppende ooreenkoms (koopkontrak), die saaklike ooreenkoms (Auflassung) en die Eintragungsbewilligung verskillende regshandelinge is, word dit dikwels gelyktydig opgestel en in dieselfde dokument vervat, ${ }^{63}$ maar die saaklike ooreenkoms kan ook eers later opgestel word. $^{64}$

Indien die verskillende handelinge nie in dieselfde dokument vervat is nie, moet die akte wat die verbintenisskeppende ooreenkoms beliggaam, uit hoofde van §925a BGB aan die notaris voorgelê word. Indien dit nie gedoen word nie, mag

$60 \S 19$ Grundbuchordnung (GBO); Wilhelm Sachenrecht 215; Wieling Sachenrecht 1992 249-250; Westermann Sachenrecht II 69. Die Eintragungsbewilligung is eensydig en word deur die vervreemder afgelê, maar hy kan aan die verkryger volmag verleen. Sien Wilhelm Sachenrecht 215. Dit wil voorkom asof hierdie dokument min of meer ooreenstem met die transportakte van die Suid-Afrikaanse en Nederlandse reg.

61 Daar word deurgaans daarna gestrewe om te verseker dat die registers met die werklikheid in ooreenstemming is. Schmitz 1994 JuS 962; Westermann Sachenrecht II 69; Wieling Sachenrecht 1992 249-250.

62 Wilhelm Sachenrecht 215-216, 291.

63 Verg §925 BGB; Wieling Sachenrecht 1992333 vn 5; Wilhelm Sachenrecht 308. Die rede waarom daar ook nog ' $n$ afsonderlike Bewilligung (toestemming) moet wees, is waarskynlik juis gerig op daardie gevalle waar die koopkontrak en die saaklike ooreenkoms gelyktydig tot stand kom.

64 Verg §925 a BGB; Wieling Sachenrecht 1992333 vn 5. 
die notaris nie die saaklike ooreenkoms opstel nie. ${ }^{65}$ Dit is nie die notaris se taak om vas te stel of die verbintenisskeppende ooreenkoms geldig is nie, maar indien daar iets is wat hom laat twyfel, of indien die gebrek ook die saaklike ooreenkoms sou kon beïnvloed, moet hy stappe doen om die gebrek uit die weg te ruim. ${ }^{66}$ Die doel met $§ 925 a$ BGB is om die vormvereistes in $\S 311 B G B$ (voorheen §313), wat op die verbintenisskeppende ooreenkoms van toepassing is (Beurkundung), af te dwing. Enersyds kan die saaklike ooreenkoms nie sonder die medewerking van 'n notaris (geskikte ampspersoon) tot stand kom nie; andersyds moet die betrokke amptenaar (notaris) sy medewerking weier indien die verbintenis nie voorgelê word nie. As dit nie vir hierdie bepaling was nie, sou die partye weens toepassing van die abstraktheidsbeginsel, die vormvereistes bloot kon ignoreer, want eiendomsreg sou nieteenstaande nietigheid van die verbintenisskeppende ooreenkoms (weens nie-nakoming van die vormvereistes) tog oorgaan en die gebreke sou uit hoofde van §311 BGB herstel kon word. ${ }^{67}$ Verdere oogmerke met $§ 925 a B G B$, is om die notaris in staat te stel om die partye in te lig aangaande die gevolge van die saaklike ooreenkoms, om dwaling te voorkom en om twyfel uit die weg ruim. Hy kan sy pligte in hierdie opsig slegs nakom, indien hy op hoogte is van die inhoud van die verbintenisskeppende ooreenkoms.

\section{$4 \quad$ Voorstelle vir veranderinge in die Suid-Afrikaanse reg}

Die bespreking hierbo betreffende die posisie in Nederland en in Duitsland, het aan die lig gebring dat daar twee moontlikhede bestaan waarvolgens die onduidelikheid in die Suid-Afrikaanse reg betreffende die bestaan van ' $n$ geldige saaklike ooreenkoms in die geval van oordrag van onroerende goed reggestel kan word, naamlik: (1) die saaklike ooreenkoms kan in 'n afsonderlike dokument geboekstaaf word, of (2) die saaklike ooreenkoms kan in die

65 Sien $\$ 925$ a BGB. Indien hy dit nogtans doen, sal die ooreenkoms nie nietig wees nie, want dit is bloot 'n Ordnungsvorschrift. Raadpleeg Wieling Sachenrecht 1992333.

66 Staudinger Sachenrecht II \$925 a Rdn 8.

67 Die abstraktheidsbeginsel word sodoende beperk. Staudinger Sachenrecht II §925 a Rdn $3,8$. 
transportakte vervat word. Hierdie moontlikhede sal vervolgens verder ondersoek word.

\subsection{Saaklike ooreenkoms op skrif gestel}

Die eerste moontlikheid is dat die saaklike ooreenkoms, na analogie van die posisie in Duitsland, tot stand kom deurdat beide partye voor 'n transportbesorger $^{68}$ verskyn en in mekaar se teenwoordigheid teenoor hom verklaar dat hulle onderskeidelik die bedoeling het om eiendomsreg oor te dra en te ontvang en dat eiendomsreg met registrasie sal oorgaan (materiële reg). Die transportbesorger moet as deel van sy ampspligte die implikasies van die saaklike ooreenkoms en die registrasieproses aan die partye verduidelik. Hy moet ook seker maak daarvan dat aan die materieelregtelike geldigheidsvereistes vir die saaklike ooreenkoms voldoen is (byvoorbeeld handelingsbevoegdheid, wilsooreenstemming, afwesigheid van bedrog ensovoort). Gebreke in die ooreenkoms, én die daarmee gepaardgaande onsekerheid, sal gevolglik tot die minimum beperk word.

Dit is nie 'n geldigheidsvereiste dat die ooreenkoms op skrif gestel moet word nie. Die verklarings kan dus mondeling afgelê word. Ten einde registrasie te bewerkstellig, moet die transportbesorger egter 'n sertifikaat opstel waarin hy bevestig dat die partye voor hom verskyn het en die onderskeie verklarings afgelê het, welke dokument saam met die aansoek om registrasie by die akteskantoor ingedien moet word. Dit dien as bewys daarvan dat die saaklike ooreenkoms tot stand gekom het (formele reg). ${ }^{69}$

68 In Nederland en in Duitsland word die notaris by die registrasieproses betrek. Hierdie notaris verskil hemelsbreed van die notaris in Suid-Afrika waar die transportbesorger min of meer die eweknie van die Duitse en Nederlandse notaris is.

69 In Duitsland moet ' $n$ öffentliche Urkunde wat deur 'n notaris opgestel is ingedien word. Notariële verlyding word egter nie vir Suid-Afrika voorgestel nie. 'n Sertifikaat deur die transportbesorger behoort voldoende te wees. Raadpleeg Carey Miller en Pope Land Title 113-114 ivm die rol wat sertifikate wat deur die transportbesorger opgestel is, in die registrasieproses vervul. 
Die feit dat daar behoorlik tussen materiële reg en formele reg onderskei word, kan aangevoer word ter regverdiging van hierdie opsie. ${ }^{70}$ Die materiële reg skryf die vereistes voor waaraan voldoen moet word ten einde oordrag van eiendomsreg te bewerkstellig, onder andere 'n geldige saaklike ooreenkoms en registrasie. Die formele reg lê weer die prosedure neer wat gevolg moet word en dit skryf voor watter dokumente voorgelê moet word ten einde registrasie te bewerkstellig. Dit vereis byvoorbeeld dat bewys van die saaklike ooreenkoms in die voorgeskrewe vorm aan die registrasiebeampte voorgelê moet word alvorens registrasie bewerkstellig kan word. 'n Praktiese gevolg van die onderskeid tussen materiële reg en formele reg is dat, indien registrasie sou plaasvind sonder dat die vereistes van die materiële reg nagekom is (indien daar byvoorbeeld nie ' $n$ saaklike ooreenkoms is nie), eiendomsreg nie sal oorgaan nie. Daarteenoor sal eiendomsreg wel oorgaan indien registrasie sou plaasvind, selfs al is daar nie aan al die vereistes van die formele reg voldoen nie (indien bewys van die saaklike ooreenkoms in die voorgeskrewe vorm byvoorbeeld nie voorgelê word nie).

Kritiek wat teen hierdie eerste moontlikheid geopper kan word, is die volgende:

(1) Dit kan tot onnodige duplisering aanleiding gee van die dokumente wat vir registrasie ingedien word. Die saaklike ooreenkoms moet, onder andere, die volgende inligting bevat: die persoonlike gegewens van die partye, ' $n$ omskrywing van die grondstuk wat oorgedra word, besonderhede van enige voorwaardes of beperkings waaraan eiendomsreg onderworpe is. Die sertifikaat wat deur die transportbesorger opgestel sal moet word, sal dus noodwendig hierdie inligting moet weergee, maar dit word reeds in die transportakte vervat. ${ }^{71}$

70 'n Onderskeid wat in die Duitse reg beklemtoon word. Raadpleeg Baur Sachenrecht 165166; Staudinger Sachenrecht I §873 Rdn 124-125; Kuntze et al Grundbuchrecht 419; Ertl 1980 Rechtspfleger 41-42, 46. Soos hieronder aangetoon sal word, onderskei die tweede moontlikheid nie behoorlik tussen hierdie twee vakgebiede nie.

71 Reg 82 uitgevaardig kragtens die Wet op Registrasie van Aktes 47 van 1937 skryf voor dat die transportakte aan vorm E moet voldoen. Sien voorts reg 18, 24, 26, 28 en 32. Raadpleeg verder Carey Miller en Pope Land Title 72-73, 87-89 92 ev; Carey Miller Acquisition 197 ev; Heyl Grondregistrasie 40, 121, 309. 
(2) Dit is omslagtig en kunsmatig om die maak van die verklarings deur die partye voor die notaris (mondelinge totstandkoming van die saaklike ooreenkoms) en die skriftelike bevestiging deur die notaris van wat die partye vir hom gesê het, van mekaar te skei. Dit skep ruimte vir misverstand en geleentheid om die ooreenkoms later te beveg. ${ }^{72}$

(3) Die voorstel dat die partye hulle verklarings in mekaar se teenwoordigheid voor die notaris moet aflê, is onprakties, veral wanneer een of beide partye in die buiteland is.

In die lig van hierdie kritiek word aan die hand gedoen dat dit nie prakties is om hierdie moontlikheid, wat op die lees van Duitsland geskoei is, net so in SuidAfrika van toepassing te maak nie. As alternatief vir hierdie opsie word voorgestel dat die transportbesorger die verklarings wat die partye voor hom aflê, op skrif stel en dat dit deur hom en die partye onderteken moet word. Die saaklike ooreenkoms sal dan in die dokument vervat word en met ondertekening van die dokument tot stand kom. Die partye hoef die verklarings nie in mekaar se teenwoordigheid af te lê, of die dokument in mekaar se teenwoordigheid te onderteken nie. Hulle kan ook verteenwoordigers gebruik maak wat met die nodige volmag namens hulle kan optree. Anders as wat in Duitsland die geval is, behoort skrif dus 'n geldigheidsvereiste vir die saaklike ooreenkoms te wees. Die rede waarom regshandelinge op skrif gestel word, is immers om regsekerheid te bewerkstellig en om te dien as bewys van die betrokke feit. Hier het dit nog 'n bykomende voordeel, naamlik om te verseker dat registrasie met die saaklike ooreenkoms ooreenstem. Hierdie dokument kan terselfdertyd dien as bewys van die saaklike ooreenkoms en dit kan saam

72 Dit is nie duidelik waarom skrif (maw die öffentliche Urkunde) nie in Duitsland 'n geldigheidsvereiste vir die saaklike ooreenkoms is nie, maar daar is sekerlik niks wat dit behoort te verhinder nie. ' $n$ Moontlike rede is dat indien skrif 'n geldigheidsvereiste is, die saaklike ooreenkoms beveg kan word indien die formaliteite nie nagekom is nie. Hierdie argument is egter nie besonder sterk nie, omdat die $B G B$ in elk geval vormvereistes voorskryf. Indien dit verontagsaam word, kan dit tot gevolg hê dat geen saaklike ooreenkoms tot stand kom nie. 
met die transportakte en ander ondersteunende dokumente by die akteskantoor ingedien word vir doeleindes van registrasie. ${ }^{73}$

\subsection{Saaklike ooreenkoms in transportakte vervat}

' $n$ Tweede moontlikheid is dat die saaklike ooreenkoms soos wat in Nederland die geval is, in die transportakte vervat word. Indien hierdie moontlikheid in Suid-Afrika toegepas sou word, sou daar benewens die oordrags- en ontheffingsklousules, ${ }^{74}$ 'n verdere klousule tot die transportakte bygevoeg moet word waarin die verkryger uitdruklik verklaar dat hy eiendomsreg aanvaar. ${ }^{75}$ Die partye moet hulle onderskeie verklarings voor die transportbesorger ${ }^{76}$ wat die akte opstel, onderteken, op welke tydstip die ooreenkoms ook tot stand kom. ${ }^{77}$ Hulle kan ook aan verteenwoordigers volmag verleen om namens hulle op te tree. Soos by die eerste moontlikheid hierbo voorgestel, moet die transportbesorger die implikasies van die saaklike ooreenkoms en die registrasieproses aan die partye verduidelik en moet hy seker maak daarvan dat aan die geldigheidsvereistes vir die saaklike ooreenkoms voldoen is. Hierdie tweede moontlikheid, kan egter ook op verskeie gronde gekritiseer word: ${ }^{78}$

a) Dit onderskei nie behoorlik tussen materiële en formele reg nie. ${ }^{79}$ Indien die saaklike ooreenkoms in die transportakte vervat sou word, sal die

73 Die regulasies wat ingevolge die Wet op Registrasie van Aktes uitgevaardig word, behoort te vereis dat bewys van die saaklike ooreenkoms voorgelê moet word alvorens registrasie kan plaasvind.

74 Waarin die vervreemder of transportbesorger as sy verteenwoordiger verklaar dat hy van sy regte op die grondstuk afstand doen en dit aan die verkryger oordra.

75 Hierdie klousule kan ook met die oordragsklousule saamgevoeg word in een enkele klousule.

76 Die eweknie van die Nederlandse notaris. In Nederland moet die transportakte deur ' $n$ notaris opgestel word (dit moet notarieel verly word).

77 'n Verteenwoordiger kan namens die partye optree, maar dit behoort nie die transportbesorger te wees voor wie die verklarings onderteken is nie.

78 Laurens Saaklike Regte 260-262 en Lötz Onroerende Goed 14, 19 en 82 is van oordeel dat die saaklike ooreenkoms nie in die transportakte vervat behoort te word nie. Lötz Onroerende Goed 101 en 103 stel voor dat die saaklike ooreenkoms notarieel verly moet word.

79 Sien bv Laurens Saaklike Regte 260-262 en Lötz Onroerende Goed 14, 19 en 82. Maar Lötz Onroerende Goed 101, 103 sê ook dat alle ooreenkomste wat eiendomsoorgang tot gevolg het (waarby die saaklike ooreenkoms sekerlik ingesluit is), onafskeidbaar deel vorm van die aktesregistrasieproses en notarieel verly moet word. Dit lyk strydig met sy standpunt dat die saaklike ooreenkoms nie in die transportakte vervat behoort te wees nie. 
onderskeid tussen materiële reg (saaklike ooreenkoms) en formele reg (lewering/registrasie) vervaag.

b) Die transportakte is ' $n$ vereiste van die formele reg (aktesregistrasie) en vorm 'n integrale deel van die registrasiehandeling (oordragshandeling), aangesien registrasie van die akte eiendomsoordrag bewerkstellig.80 As sodanig vervul dit 'n leweringsfunksie. Dit is die geleibuis deur middel waarvan die reg van die vervreemder op die verkryger oorgedra word. ${ }^{81}$

c) Aangesien die transportakte 'n vereiste van die formele reg (aktesregistrasie) is, is dit nie bedoel om materieelregtelike vereistes, soos die saaklike ooreenkoms, te beliggaam nie.

d) Die transportakte is die eienaar se titelakte wat na registrasie as bewys dien van sy eiendomsreg ${ }^{82}$ en is nie veronderstel om regshandelinge tussen die partye te beliggaam nie. Dit behoort nie op grond van nietigheid van die regshandeling beveg te kan word nie.

e) Die saaklike ooreenkoms behoort nie in die transportakte vervat te word nie, omdat verskillende geldigheidsvereistes op onderskeidelik die saaklike ooreenkoms en die transportakte van toepassing is. ${ }^{83}$

Nieteenstaande hierdie kritiek kan die volgende argumente weer aangevoer word ter regverdiging van die voorstel dat die saaklike ooreenkoms in die transportakte vervat word:

i) Die transportakte is meer as net 'n vereiste van die formele reg wat vir doeleindes van registrasie aangewend word.84 Afgesien daarvan dat dit as titelakte dien waardeur die vervreemder se eiendomsreg bewys word, bevat dit ook materieelregtelike bepalings wat die sakeregtelike verhouding ten

80 Art 16 van die Wet op Registrasie van Aktes 47 van 1937 bepaal dat grond slegs oorgedra kan word deur middel van 'n transportakte wat deur die Registrateur onderteken of geattesteer word. Verder Carey Miller en Pope Land Title 70-71, 82-83; Heyl Grondregistrasie 22.

81 Dit kan ook gesien word as 'n simbool van die reg wat oorgedra word. Registrasie is dus 'n vorm van simboliese lewering.

82 Sien Carey Miller en Pope Land Title 70-71, 82.

83 In Duitsland is die vereistes van die materiële reg betreffende regshandelinge nie op die toestemming van toepassing nie en dit behoort ook nie op die transportakte van toepassing te wees nie.

84 Dit is meer as 'n element van die oordragshandeling en nie bloot 'n geleibuis nie. 
opsigte van 'n bepaalde grondstuk wesenlik kan beïnvloed, ${ }^{85}$ soos byvoorbeeld voorwaardes waardeur eiendomsreg beperk word. In elk geval is die verklaring in die transportakte deur die vervreemder dat hy eiendomsreg oordra, die vergestalting van 'n vereiste van die materiële reg.

ii) Daar bestaan in Suid-Afrika ook ander situasies waar materiële reg en formele reg met mekaar vermeng word. ${ }^{86}$ Die vestiging of oordrag van beperkte saaklike regte geskied byvoorbeeld deur die registrasie van 'n notariële akte wat nie net die materieelregtelike ooreenkoms tussen die partye bevat nie, maar ook die saaklike ooreenkoms. ${ }^{87}$ Gewoonlik aanvaar die verkryger die reg wat oorgedra word aan die einde van die akte. Dit is dus 'n tweesydige akte waaraan beide partye meewerk, deurdat hulle voor die notaris in wie se teenwoordigheid die akte verly word, verskyn. Die feit dat die saaklike ooreenkoms in die transportdokument vervat word, is dus nie 'n vreemde verskynsel in Suid-Afrika nie. ${ }^{88}$

iii) 'n Verdere aanknopingspunt kan gevind word by die praktyk wat op skenkings van toepassing is, in welke geval vereis word dat die skenking deur die verkryger aanvaar moet word (wat ook 'n vereiste van die materiële reg is). ${ }^{89}$ Vorm $E$ maak daarvoor voorsiening dat die skenking in die transportakte (aan die einde daarvan) deur 'n transportbesorger (wat vir hierdie doel aangestel is) aanvaar word, of daar kan in die relaas van die akte gesê word dat die skenking aanvaar is en bewys kan gelewer word dat dit wel gedoen is. ${ }^{90}$

iv) Hierdie voorstel is nie verreikend nie en maklik om toe te pas. Aspekte wat op die inhoud van die saaklike ooreenkoms betrekking het, is byvoorbeeld reeds in die transportakte vervat, naamlik: die persoonlike gegewens van die partye, 'n omskrywing van die saak wat oorgedra word, besonderhede

85 In hierdie opsig verskil dit van die dokument wat die verbintenis beliggaam en die verbintenisregtelike verhouding tussen die partye tot uiting bring.

86 Vermenging van die twee vakgebiede, is blykbaar ook in Nederland geen probleem nie.

87 Dit is dus ' $n$ dokument wat tot die materiële reg en die formele reg behoort.

88 Die feit dat die notariële akte die verbintenisregtelike ooreenkoms tussen die partye beliggaam, terwyl die transportakte geen ooreenkoms is nie, mag 'n rede wees waarom hierdie voorstel nie algemene aanvaarding sal vind nie.

89 Aanknopingspunte vir die standpunt dat die bedoeling uit die transportakte moet blyk, kan ook in die regspraak gevind word. Verg bv Gardens Estate v Lewis 1920 AD 144 en Meyers v Van Heerden 19662 SA 649 (K) 655-656.

90 Sien Heyl Grondregistrasie 159. 
van enige voorwaardes of beperkings waaraan eiendomsreg onderworpe is. Soos hierbo aangetoon is, sal slegs geringe wysigings aan die transportakte aangebring hoef te word en sal beide partye voor die transportbesorger moet verskyn.

Indien dit so is dat die materiële reg en die formele reg ten alle koste uitmekaar gehou moet word en indien die feit dat die saaklike ooreenkoms in die transportakte vervat is, die twee vakgebiede sal vermeng, is daar een van twee opsies: (1) die saaklike ooreenkoms moet op skrif gestel word (die alternatief by die eerste moontlikheid hierbo) of (2) daar kan vereis word dat die partye hulle mondelinge verklarings in mekaar se teenwoordigheid voor die transportbesorger aflê $\hat{e}^{91}$ en dat hy in die transportakte bevestig dat die saaklike ooreenkoms tot stand gekom het. ${ }^{92}$ Hierdie voorstel is soortgelyk aan die eerste moontlikheid, behalwe dat bevestiging deur die transportbesorger in die transportakte en nie by wyse van 'n sertifikaat plaasvind nie.

\section{$5 \quad$ Samevatting en aanbevelings}

Geen vormvereistes is in Suid-Afrika op die saaklike ooreenkoms van toepassing nie, met die gevolg dat dit nie in 'n uiterlik waarneembare handeling of dokument tot uiting kom nie. Die bespreking in hierdie artikel het aangetoon dat dit as 'n leemte in die Suid-Afrikaanse reg aangemerk kan word en dat daar ' $n$ behoefte bestaan aan bewyskragtige getuienis betreffende die vraag, of en indien wel op watter tydstip, 'n geldige saaklike ooreenkoms tot stand gekom het. Daar word gevolglik aan die hand gedoen dat vormvereistes op die saaklike ooreenkoms by die oordrag van onroerende goedere van toepassing gemaak behoort te word. Daar is een van twee moontlikhede:

91 Op welke wyse en tydstip die saaklike ooreenkoms tot stand kom.

92 Die transportakte dien dan as bewys daarvan dat die saaklike ooreenkoms tot stand gekom het. Die verkryger sal in hierdie geval ook 'n skriftelike volmag aan die transportbesorger moet verleen om namens hom op te tree. Die praktyk op die oomblik is dat hy optree uit hoofde van 'n skriftelike volmag deur die vervreemder. 
(1) Die partye of hulle verteenwoordigers kan voor 'n transportbesorger verskyn wat die transportakte opstel en uitdruklik voor hom verklaar dat hulle onderskeidelik die bedoeling het om eiendomsreg oor te dra en te ontvang. Hy moet ook daarvan seker maak dat aan die materieelregtelike geldigheidsvereistes vir die saaklike ooreenkoms voldoen is. Die transportbesorger moet die verklarings op skrif stel, en die dokument moet deur hom en die partye onderteken word. Die saaklike ooreenkoms sal dan tot stand kom met ondertekening van die dokument. Die partye kan die dokument persoonlik onderteken of van 'n behoorlik skriftelik gemagtigde verteenwoordiger gebruik maak. Hierdie dokument moet aan die Registrateur voorgelê word as bewys daarvan dat die ooreenkoms inderdaad tot stand gekom het. ${ }^{93}$

(2) Die saaklike ooreenkoms kan in die transportakte vervat word, in welke geval die akte soos dit tans daar uitsien, in 'n geringe mate gewysig sal moet word, sodat dit verklarings deur beide partye bevat te dien effekte dat eiendomsreg oorgedra en verkry word. Daar word voorgestel dat 'n verdere klousule, benewens die oordrags- en ontheffingsklousules, tot die transportakte bygevoeg moet word, waarin die verkryger uitdruklik verklaar dat hy eiendomsreg aanvaar. Die transportakte (of die betrokke klousules wat hulle verklarings bevat) moet deur beide partye onderteken word. ${ }^{94}$ Ook hier behoort dit moontlik te wees dat die partye verteenwoordig kan word ingevolge 'n skriftelike volmag.

In beginsel is daar nie werklik enige rede waarom die een bo die ander verkies moet word nie. Enige van hierdie opsies sal die moontlikheid van 'n foutiewe register by die afgeleide wyses van eiendomsverkryging verskraal en die negatiewe eienskappe van die stelsel uitskakel. Aangesien daar geen twyfel betreffende die bestaan van die saaklike ooreenkoms meer sal wees nie, kan makliker aanvaar word dat die registers inderdaad die regsposisie ten opsigte

93 Hierdie voorstel stem ooreen met die alternatief tot die eerste moontlikheid wat hierbo bespreek is.

94 Dit vervang nie die huidige praktyk wat vereis dat die transportbesorger voor die Registrateur verskyn en die dokument deur hom verly word nie, dit is aanvullend daartoe. 
van ' $n$ bepaalde grondstuk korrek weergee, wat regsekerheid in die hand sal werk.

\section{Bibliografie}

Algra Burgerlijk Recht

Algra NE Inleiding tot het Nieuw Burgerlijk Recht 4e uitg (Wolters-Noordhoff Groningen 1983)

\section{Asser-Beekhuis Zakenrecht}

Asser C "Zakenrecht" in Beekhuis JH Handleiding tot de Beoefening van het Nederlands Burgerlijk Recht: Zakenrecht Algemeen Deel 1 (WEJ Tjeenk Willink Zwolle 1980)

Asser-Mijnssen Goederenrecht

Asser C "Goederenrecht" in Mijnssen FHJ et al (red) Handleiding tot de Beoefening van het Nederlands Burgerlijk Recht: Derde Deel 14e uitg (Kluwer Deventer 2001)

Asser-Mijnssen Zakenrecht

Asser C "Zakenrecht" in Mijnssen FHJ en De Haan P (red) Handleiding tot de Beoefening van het Nederlands Burgerlijk Recht: Deel I Algemeen Goederenrecht 13e uitg (WEJ Tjeenk Willink Zwolle 1992)

Badenhorst, Pienaar en Mostert Property

Badenhorst PJ, Pienaar JM en Mostert H Silberberg and Schoeman's The Law of Property 5e uitg (LexisNexis Butterworths Durban 2006)

Baur Sachenrecht

Baur F "Sachenrecht" in Baur JF en Stürner R (verw) Sachenrecht 17e uitg (Beck München 1999)

Carey Miller Acquisition

Carey Miller DL The Acquisition and Protection of Ownership (Juta Kaapstad 1986) 
Carey Miller en Pope Land Title

Carey Miller DL en Pope A Land Title in South Africa (Juta Kenwyn 2000)

Ertl 1980 Rechtspfleger

Ertl R "Antrag, Bewilligung und Einigung im Grundstücks- und

Grundbuchrecht" 1980 Der Deutsche Rechtspfleger 41-51

Fuchs-Wissermann 1977 Rechtspfleger

Fuchs-Wissermann $\mathrm{H}$ "Zur Form der Auflassung nach $\S 925$ Abs. 1 Sätze 1

u. 2 BGB und der Einigung nach den § 20, 29 Abs. 1 GBO" 1977 Der

Deutsche Rechtspfleger 8-12

Fuchs-Wissermann 1978 Rechtspfleger

Fuchs-Wissermann H "Abermals: Form und Nachweis der Auflassung"

1978 Der Deutsche Rechtspfleger 431-433

Haegele 1967 Rechtspfleger

Haegele K "Urkundenvorlage beim Grundbuchamt" 1967 Der Deutsche Rechtspfleger 33-37

Heyl Grondregistrasie

Heyl JWS Grondregistrasie in Suid-Afrika (Juridata Pretoria 1977)

Huhn 1977 Rechtspfleger

Huhn D "Nochmals: Form und Nachweis der Auflassung" 1977 Der

Deutsche Rechtspfleger 199-201

Nel Jones - Conveyancing

Nel HS Jones - Conveyancing in South Africa 4e uitg (Juta Kaapstad 1991)

Kuntze Grundbuchrecht

Kuntze J et al Grundbuchrecht: Kommentar zu Grundbuchordnung und

Grundbuchverfügung einschliesslich Wohnungseigentumsgrundbuchverfügung 4e uitg (W de Gruyter Berlyn 1991)

Laurens Saaklike Regte

Laurens RC Die Ontstaan en Tenietgaan van Saaklike Regte in die lig van $28 / 32$ 
die Suid-Afrikaanse Stelsel van Aktesregistrasie (LL D proefskrif UNISA 1980)

Lötz Onroerende Goed

Lötz DJ Lewering van Onroerende Goed in die Suid-Afrikaanse Reg: 'n Kritiese Vergelyking Tussen Oordrag by wyse van Endossement en by wyse van Transportakte (LLM verhandeling WITS 1987)

Mijnssen en Schut Levering en Overdracht

Mijnssen FHJ en Schut GHA Bezit, Levering en Overdracht 3e uitg (WEJ Tjeenk Willink Zwolle 1991)

Pienaar 1986 CILSA

Pienaar GJ "A Comparison between Some Aspects of South African Deeds Registration and the German Registration System" 1986 Comparative and International Law Journal of Southern Africa 236

Pitlo-Reehuis Goederenrecht

Pitlo A "Goederenrecht" in Reehuis WHM en Heisterkamp AHT Nederlands Burgerlijk Recht Deel 3 10e uitg (Gouda Quint Arnhem 1994)

Schmitz 1994 JuS

Schmitz K "Methodik der Fallbearbeitung für Referendare: Wegweiser durch das Grundbuchverfahren" 1994 Juristische Schulung 962

Schoeman en Schoeman Property

Silberberg H en Schoeman J The Law of Property 2e uitg (Butterworth Durban 1983)

Snijders en Rank-Berenschot Goederenrecht

Snijders HJ en Rank-Berenschot EB Goederenrecht (Kluwer Deventer 1994)

Staudinger Sachenrecht I

Staudinger J von Kommentar zum Bürgerlichen Gesetzbuch Drittes Buch Sachenrecht Einleitung zu § 854ff, §§ 854-902 12e uitg (J Schweitzer Berlyn 1989) 
Staudinger Sachenrecht II

Staudinger J von Kommentar zum Bürgerlichen Gesetzbuch Drittes Buch

Sachenrecht §§ 903-931, Anhang zu §§929-931, §§932-936 12e uitg (J

Schweitzer Berlyn 1989)

Van der Merwe Sakereg

Van der Merwe CG Sakereg 2e uitg (Butterworth Durban 1989)

Van Rensburg en Van der Merwe 1978 THRHR

Van Rensburg ADJ en Van der Merwe CG "Die Aard van Besit en die

Animus-element daarvan" 1978 Tydskrif vir die Hedendaagse Romeins-

Hollandse Reg 113-130

Voet ad Digesta 41.1.38

Voet J (1647-1713) Commentarius ad Pandectas (Lugduni Batavorum

Leiden 1698)

Westermann Sachenrecht I

Westermann H "Sachenrecht" Band I in Westermann HP, Gursky K en

Pinger W (red) Grundlagen und Recht der Beweglichen Sachen 6e uitg (CF

Müller Heidelberg 1990)

Westermann Sachenrecht II

Westermann H "Sachenrecht" Band II in Eickmann D en Pinger W (red)

Immobiliarsachenrecht 6e uitg (CF Müller Heidelberg 1988)

Wieling Sachenrecht 1990

Wieling HJ Sachenrecht Band I Sachen, Besitz und Rechte an

Beweglichen Sachen (Springer-Verlag Berlyn 1990)

Wieling Sachenrecht 1992

Wieling HJ Sachenrecht (Springer-Verlag Berlyn 1992)

Wilhelm Sachenrecht

Wilhelm J Sachenrecht 2e uitg (Springer-Verlag Berlyn 2002)

\section{Register van wetgewing}

Beurkundungsgesetz 1969 
Bürgerliches Gesetzbuch 1900

Bundesnotarordnung 1961

Gesetz über die Angelegenheiten der freiwilligen Gerichtsbarkeit 1898

Grundbuchordnung 1994

Kadasterwet 1989

Nieuw Burgerlijk Wetboek 1992

Wet op het Notarisambt 1956

Wet op Registrasie van Aktes 47 van 1937

Zivilprozeßordnung 1966

\section{Register van hofsake}

Desai v Desai 19961 SA 141 (A) 148-149

Erikson Motors v Protea Motors 19733 SA 685 (A) 694

Freye's v Ries 19573 SA 575 (A) 582

Gardens Estate v Lewis 1920 AD 144

Meyers v Van Heerden 19662 SA 649 (K) 655-656

Preller and Others $v$ Jordaan 19561 SA 483 (A)

Weeks v Amalgamated Agencies 1920 AD 218

\section{Lys van afkortings}

art artikel(s)

bv byvoorbeeld

BeurkG Beurkundungsgesetz

BGB Bürgerliches Gesetzbuch

BnotO Bundesnotarordnung

CILSA Comparative and International Law Journal of Southern Africa

ev en verder

FGG Gesetz über die Angelegenheiten der freiwilligen Gerichtsbarkeit

GBO Grundbuchordnung

JuS Juristische Schulung

NBW Nieuw Burgerlijk Wetboek

par paragraaf/paragrawe

Rechtspfleger Der Deutsche Rechtspfleger 
reg

THRHR

verg

ZPO regulasie(s)

Tydskrif vir die Hedendaagse Romeins-Hollandse Reg vergelyk

Zivilprozeßordnung 